\title{
META-ANALYSIS: ACUPUNCTURE THERAPY IN REDUCING BLOOD PRESSURE ON HYPERTENSIVE PATIENTS
}

\author{
Fahmi Eko Susilo'), Hanung Prasetya'), Agus Kristiyanto3)
}

\author{
${ }^{1)}$ Masters Program in Public Health, Universitas Sebelas Maret \\ ${ }^{2)}$ Study Program in Acupuncture, Health Polytechnics, Ministry of Health, Surakarta \\ 3)Study Program in Sports Education and Health Sciences, Universitas Sebelas Maret
}

\begin{abstract}
Background: Blood pressure control is an important component of cardiovascular disease prevention. Despite the advances in the treatment of hypertension; effective management remains poor. Studies have shown that acupuncture facilitated a significant reduction in blood pressure. The purpose of this study was to examine the effectiveness of acupuncture therapy in reducing blood pressure on hypertensive patients.

Subjects and Method: This was a meta-analysis and systematic review. The study was conducted by collected articles from PubMed, Google Schoolar, Mendeley, and Hindawi databases. Keywords used "acupuncture hypertension" OR "acupuncture high blood pressure" AND "efficacy acupuncture" AND "hypertension" AND "effect acupuncture for hypertension" AND "randomized controlled trial" AND "visual analogue scale". The study population was patients with hypertension. The intervention was acupuncture. The comparison was sham acupuncture. The outcome was blood pressure reduction. The inclusion criteria were full text with English language and using randomized controlled trial study design. The selected articles were analyzed by PRISMA flow diagram and RevMan 5.3.

Results: 7 articles were studied. There was high heterogeneity between experiment groups $\left(I_{2}=\right.$ $66 \% ; p=0.007)$. Acupuncture therapy was more effective to reduce blood pressure than sham acupuncture (Standardized Mean Difference $=0.13 ; 95 \% \mathrm{CI}=-0.13$ to $0.39 ; \mathrm{p}=0.320$ ).

Conclusion: Acupuncture therapy is effective to reduce blood pressure in patients with hypertension.
\end{abstract}

Keywords: hypertension, acupuncture

\section{Correspondence:}

Fahmi Eko Susilo. Masters Program in Public Health, Universitas Sebelas Maret. Jl. Ir. Sutami 36A, Surakarta 57126, Central Java. Email: fahmiekss@gmail.com. Mobile: o81393644991.

The $7^{\text {th }}$ International Conference on Public Health

Solo, Indonesia, November 18-19, 2020 | 421 https://doi.org/10.26911/the7thicph.05.53 